DOI: 10.17951/bc.2020.5.95-109

\begin{tabular}{lcr}
\hline & ANNALES \\
& & \\
UNIVERSITATIS MARIAE CURIE-SKLODOWSKA & \\
LUBLIN - POLONIA & \\
VOL.V & SECTIO M & 2020 \\
\hline
\end{tabular}

\title{
Damian Wicherek
}

University of Rzeszow

E mail: wicherekdamian@gmail.com

ORCID ID: 0000-0002-1710-0820

\section{Program assumptions of Zbigniew Ziobro's Solidary Poland in the years 2012-2014}

\section{Introduction}

Zbigniew Ziobro's Solidary Poland (SPZZ), began its activity in the public and political space in the spring of 2012 and was based on two pillars. One was its members and structures in the field, who, through their activity, tried to convince the public to vote for them, while the other tool, which caused an increase in public support, was a program declaration. As a given political group is positioned on the left-right-center axis ${ }^{1}$ based upon its defined political program, with regard to SPZZ it should be stated that it is a party with right wing orientation, declaring conservative views ${ }^{2}$.

As Ryszard Herbut points out, conservative parties are in favour of traditional values, a market economy, the idea of a responsible and strong state that actively

1 See more: K. Kowalczyk, Rodzina partii politycznych w III RP, [in:] Partie i Systemy Partyjne w III RP, ed. K. Kowalczyk, Toruń 2011, p. 214; W. Sokół, Partie polityczne i systemy partyjne w Polsce w latach 1991-2001, [in:] Wspótczesne partie i systemy partyjne. Zagadnienia teorii i praktyki politycznej, ed. W. Sokół, M. Żmigrodzki, Lublin 2003, pp. 205-258; W. Sokół, Podziaty wedtug kryterium ideologicznego i programowego. Rodziny ideologiczne partii politycznych, [in:] Wspótczesne partie i systemy partyjne, ed. W. Sokół, M. Żmigrodzki, Lublin 2003, p. 38.

2 More on this topic in the following article. 
participates in the process aimed at providing its citizens with both economic and social security ${ }^{3}$.

An important element of the activity of any political party is the power to convince and win votes. According to Mariusz Gulczyński, "politically active forces used to influence social behaviour in many ways - both by positive methods - persuading and overcoming contradictions of interests through negotiations and compromises, and by negative methods - manipulation, contesting coercion and violence" ${ }^{\text {. }}$. Zbigniew Ziobro's Solidary Poland in order to achieve his goals in politics, which should be understood as "the art of achieving set goals" ${ }^{\text {" has }}$ been able to convince voters, among others through the program, so as to become an active party, capable of undertaking a number of political initiatives.

The article presents the following hypothesis - that the political activity of SPZZ is specifically intended to did not threaten the political position of Law and Justice (PiS). In order to verify the adopted hypothesis the following research questions were asked: 1 ) how did SPZZ politicians try to convince voters to accept their program proposals?; 2) what program initiatives did SPZZ politicians undertake in 2012-2014?

In order to verify the hypothesis and answer the research questions raised above, several research techniques and methods were used, among which mainly content analysis was dominant. Its subject matter was the program declaration, program initiatives from the political party's website and articles from dailies and weeklies that described the activity of the political party in 2012-2014. The basis for presenting the program assumptions were documents from the SPZZ website obtained in 2015.

\section{Program assumptions}

The SPZZ program declaration entitled: New Hope was announced during the founding congress of the party, March 24, 2014 in Otrębusy. It contained a number of proposals for changes in the social, political and economic life of the country. It was divided into two parts: the social-economic program and the political program ${ }^{6}$.

\footnotetext{
pp. $174-175$.

${ }^{3}$ R. Herbut, Teoria i praktyka funkcjonowania partii politycznych, Wrocław 2002,

4 M. Gulczyński, Nauka o polityce, Warsaw 2007, p. 93.

5 M. Chmaj, M. Żmigrodzki, Wprowadzenie do teorii polityki, Lublin 1996, p. 19.

${ }^{6}$ Home page Zbigniew Ziobro's Solidary Poland, Programme Declaration New Hope, http://solidarnapolska.pl/program, on-line: 08.11.2015; [b.a.], Solidarna Polska pokazała nowe logo i spot promujacy kongres założycielski, gazetaprawna.pl, on-line: 08.11.2015.
} 
With regard to issues related to the economy and social life, the party opted for a pro-family policy, which was considered particularly important in the times of Poland's threatening demographic crisis. The SPZZ politicians advocated financial benefits in the amount of 1000 PLN to support the child and extension of maternity leaves to 6 and 9 months in the case of the birth of the first and second child and to 12 months after the birth of the third child. The party's program also included proposals concerning the pension system and prevention of the threat of its collapse in the future years. The party also expressed its opposition to the law extending the retirement age to 67. They argued their position on the existence of high-risk professions and those in which work at the age of 67 is practically impossible (e.g. mining). On the issue of health care, the party focused on issues concerning the shortening of queues for specialty doctors and the withdrawal from life of regulations in the light of which patients paid for reimbursed drugs ${ }^{7}$. During the party's congress in December 2013, Zbigniew Ziobro spoke about countering corruption and the introduction of a bank tax, the income from which could be used for child benefits, amounting to 700 zlotys per month ${ }^{8}$.

Zbigniew Ziobro's Solidary Poland also proposed tax changes, on differentiation of tax rates and restoring the tax on fortune, which would include inheritances and donations over 2 million zlotys. The party also placed great emphasis on entrepreneurship, of which small and medium-sized companies should be the pillar. Tax reliefs, the de-bureaucratization of offices and changes concerning privatization of state enterprises were proposed. The introduction of the climate package was questioned, as well as the construction of a nuclear power plant, because it would hit the Polish economy, which is largely based on coal. As far as agriculture is concerned, Solidary Poland announced that it would prepare laws that would help Polish farmers to purchase land more easily. Moreover, the party drew attention to the need to reform the Agricultural Social Insurance Fund (Kasa Rolniczego Ubezpieczenia Społecznego) and make changes in direct payments to farmers 9 .

The second part of the program made reference to the broadly understood notions of freedom and civil liberties. As noted during the Civic Platform (PO) rule, these rights were, according to Solidary Poland, restricted. A quoted example was the struggle of TV Trwam for a place on the digital multiplex. The program

7 Home page Zbigniew Ziobro's Solidary Poland, Programme Declaration New Hope, op. cit; P. Majewski, Ziobro: 700 zt na dziecko, "Rzeczpospolita", 16.12.2013, no 292, p. A6.

8 Home page Zbigniew Ziobro's Solidary Poland, Programme Declaration New Hope, op. cit.

9 Ibidem. 
declared the abolition of immunity, not only for MPs, but also for prosecutors and judges, anti-crime legislation and the prohibition of drug licenses. In terms of local government issues, a civic legislative initiative was supported, the aim of which is to create provincial conventions, formed by the mayors and starosts of the province. The subject of the work of this group was to approve annually, projects proposed by the voivodeship board. As far as Poland's place in the European Union was concerned, SPZZ expressed its opposition to some of the provisions of the Treaty of Lisbon that held federal and centralistic assumptions, and postulated maintaining the zloty as the national currency. In international politics, the party's platform paid attention to the maintenance of correct relations with Russia and cooperation with Central and Eastern European countries in the European Union ${ }^{10}$.

As part of the party's program, SPZZ planned to initiate a number of activities concerning changes in the social and economic life of the country. They were listed in table no. 1.

Table no. 1. Zbigniew Ziobro's Programme Initiatives of Solidary Poland

\begin{tabular}{|l|l|l|}
\hline \multicolumn{1}{|c|}{ Political } & \multicolumn{1}{|c|}{ Social } & \multicolumn{1}{|c|}{ Economic } \\
\hline Security & Health care & Economy \\
New constitution & Workplaces & Climate change package \\
For women (Regional & For young people & Roads \\
Women's Forum) & Railroads \\
& Pensioners & \\
& Not for stealing & \\
& Schools & \\
& Pedophile register & \\
& Family & \\
& For students & \\
\hline
\end{tabular}

Source: Own elaboration on the basis of: Home page Zbigniew Ziobro's Solidary Poland, Programme initiatives of Solidary Poland, http://www.solidarna.org.pl, on-line: 28.05.2015.

The group of political initiatives included a proposal of changes in the area of security, changes to the Constitution and the creation of what was called the Regional Women's Forces. With regard to the first, SPZZ referred back to the times when Z. Ziobro was Minister of Justice. The party also advocated free legal aid, a rigorous fight against corruption, tightening of the penal code, an anti illicit drug program and a change in the laws that would not allow murderers and paedophiles to go free. SPZZ also declared changes in the law that would be more beneficial to victims ${ }^{11}$. In the New Constitution initiative, the party proposed to

\section{Ibidem.}

${ }^{11}$ Home page Zbigniew Ziobro's Solidary Poland, Security, http://www.solidarna.org.pl/ blogroll/bezpieczenstwo, on-line: 28.05.2015. 
change the political system in Poland: "We want to change the system of power, the presidential system, the new electoral law and other radical changes"12. SPZZ believed that the change in the Constitution was necessary due to the weakness that emerged during in the relationship between president and government and the lack of public trust in state institutions. Hence, SPZZ proposed universal suffrage with regard to the Marshal of the Voivodeship, the Starosts and the General Prosecutor, as well as changes in the electoral law and the abolition of immunities. The party came up with a postulate that had already appeared several times in Polish politics, i.e. liquidation of the Senate and reduction of the number of deputies from 460 to $230^{13}$. Another important initiative was to establish the District Women's Fora (OFK). This intent was aimed at encouraging women to actively participate in politics and support SPZZ. The project assumed the establishment of OFKs in all districts in the country, so as to allow women to have greater input into local government policy, and nationally, on the drafting of laws ${ }^{14}$.

Z. Ziobro's SPZZ also presented a number of proposals for changes in various areas of life under the slogans: Health care, Workplaces, Pensioners, Not for theft, Schools. With regard to the first initiative, they postulated the creation of a list of reimbursed drugs in cooperation with medical authorities, restoring medical care in schools, and changes in the contracting of hospitals with the National Health Fund. The party also criticized the state of Poland's health service, particularly the long queues, the lack of specialist doctors, and the negative changes introduced by the reimbursement law. SPZZ proposed to amend the Act on Drug Reimbursement of May 12, 2011, the Act on the Education System, which would include a provision on medical care in schools, and the Act on Family Planning, Protection of the Human Fetus and Conditions of Permissibility of Termination of Pregnancy ${ }^{15}$.

In the Workplace Initiative, SPZZ advocated raising the minimum wage to $50 \%$ of the basic salary and increasing the importance of vocational education. The party also announced an initiative to reduce employment on so-called 'junk contracts' and the simplification of administrative procedures. SPZZ also postulated a counter to so-called "grey zone", changes in the laws about the remu-

${ }^{12}$ Home page Zbigniew Ziobro's Solidary Poland, New Constitution, http://www.solidarna. org.pl/blogroll/nowa-konstytucja, on-line: 28.05.2015.

${ }^{13}$ Ibidem.

${ }^{14}$ Home page Zbigniew Ziobro's Solidary Poland, District Women's Fora, http://www.solidarna.org.pl/blogroll/dla-kobiet, on-line: 28.05.2015.

${ }^{15}$ Home page Zbigniew Ziobro's Solidary Poland, Health, http://www.solidarna.org.pl/ blogroll/ochrona-zdrowia, on-line: 28.05.2015. 
neration of persons managing certain legal entities, about tourist services and the Teacher's Charter"16.

Through the initiative, Pensioners, SPZZ, expressed its dissatisfaction with the policy pursued by the government of PO and Polish Peasant Party (PSL). They criticized the amount dispersed as pensions, as well as the retirement age being raised to 67 . Furthermore, they advocated a more effective pro-family policy that would result in better demographic prospects, postulated an exemption from tax on the first 1000 zloty of pension per month, and proposed changes to the laws on pensions (both for civilian and uniformed workers) ${ }^{17}$.

In the proposal Not for stealing, the base value of 400 zloty the exceeding of which could qualify theft as a crime that was introduced by the government was criticized. In the Sejm, Z. Ziobro stated: "The amendment to the Penal Code is a great gift for criminals. The PO and PSL are paying their debt to people from prisons who so eagerly supported their party in the elections. These changes are a bomb for an effective fight against crime. It will have fatal consequences for ordinary citizens"18.

Zbigniew Ziobro's Solidary Poland also included education in their proposals. The party proposed changes to curricula, increasing the number of hours of history in schools, free meals and an electronic form of textbooks that anyone could download from the website of the Ministry of National Education ${ }^{19}$. The Family Program is a SPZZ initiative addressed to young married couples, which assumes the introduction of a subsidy of 500 PLN per child per month, free nurseries and kindergartens, longer maternity leaves, the establishment of a new institution of the Family Ombudsman, increasing tax relief per child, as well as the conduction of better social policy ${ }^{20}$.

In October 2013, the politicians of SPZZ declared to submit to the Sejm a bill on the National Registry of Paedophiles, in which each employer would be obliged to check the history of any person working with children. SPZZ also announced changes in the penal code, which would include the principle

\footnotetext{
${ }^{16}$ Home page Zbigniew Ziobro's Solidary Poland, About work, http://www.solidarna.org.pl/ blogroll/miejsca-pracy, on-line: 28.05.2015.

${ }^{17}$ Home page Zbigniew Ziobro's Solidary Poland, Pensioners, http://www.solidarna.org.pl/ blogroll/emeryci-i-rencisci, on-line: 28.05.2015.

${ }^{18}$ Home page Zbigniew Ziobro's Solidary Poland, Not for stealing, http://www.solidarna. org.pl/blogroll/nie-dla-kradziezy, on-line: 28.05.2015.

${ }^{19}$ Home page Zbigniew Ziobro's Solidary Poland, http://www.solidarna.org.pl, on-line: 28. 05. 2015.

${ }^{20}$ Home page Zbigniew Ziobro's Solidary Poland, Family, http://www.solidarna.org.pl/ blogroll/rodzina,on-line: 28.05.2015.
} 
of "twice and after a paedophile". This meant that a repeat offender would be sentenced to life imprisonment ${ }^{21}$.

The last group of programme initiatives include those relating to the economy, the climate and roads and rail infrastructure.

The Economy Initiative, contained a number of SPZZ proposals aimed at revitalizing the economic market, creating better conditions for entrepreneurs and employees, limiting the privatization of economic sectors of particular importance for the state, developing innovation and vocational education ${ }^{22}$. The draft Climate Package was distributed on a European scale. Its originator was Ludwik Dorn. The action was to collect one million signatures for the European Citizens' Initiative for the European Commission to suspend the Climate Package, which, according to the SPZZ politicians, would cause an increase in energy prices in Poland in the coming years from 60 to 80\%. On August 8, 2012, the European Commission registered the initiative "Suspension of the EU Climate and Energy Package". Committees supporting the initiative at both national and European level were created, and the "Package, Stop" team was established in the Polish Parliament ${ }^{23}$.

Apart from the program declaration, SPZZ included directions of development and communicated the political philosophy of the party in an ideological declaration in which it referred to the teaching of Pope John Paul II. This contained provisions concerning the strengthening of the national community, the place of religion in the public space, social solidarity, respect for civil liberties and freedoms and the positioning of the family as a basic social cell ${ }^{24}$.

${ }^{21}$ Home page Zbigniew Ziobro's Solidary Poland, Pedophile register, http://www.solidarna. org.pl/blogroll/rejestr-pedofilow, on-line: 28.05.2015; Twitter, Jacek Kurski's profile, information from 17.10.2015 "Tomorrow SPZZ will submit to the Sejm a bill on the national register of paedophiles, all paedophiles, whoever they are. This is a real fight against the problem", twitter.com, https://twitter.com/kurskipl/status/390915444426964993, on-line: 28.05.2015.

${ }^{22}$ Home page Zbigniew Ziobro's Solidary Poland, Economy and entrepreneurship, http:// www.solidarna.org.pl/blogroll/gospodarka, on-line: 28.05.2015.

${ }^{23}$ Home page Zbigniew Ziobro's Solidary Poland, Stop expensive energy, http://www.solidarna.org.pl/blogroll/pakiet-klimatyczny, on-line: 28.05.2015.

${ }^{24}$ Home page Zbigniew Ziobro's Solidary Poland, Declaration of ideas, http://www.solidarna.org.pl/deklaracjaideowa, on-line: 28.05.2015. 


\section{SPZZ's program activities}

Zbigniew Ziobro's Solidary Poland began preparing party initiatives before the founding congress in Otrębusy. A first demand in February 2012 was for the dismissal of Bogdan Zdrojewski from the position of Minister of Culture and National Heritage. They justified their actions by the fact that Minister B. Zdrojewski did not conduct sufficient public consultations related to the ACTA agreement, which was signed by Poland. SPZZ prepared a motion of censure for B. Zdrojewski, and asked for all parliamentary parties, excluding the ruling party, the PO, to support the initiative. According to the "Rzeczpospolita" daily, initial support was provided by the Palikot Movement and the Democratic Left Alliance, while the motion was not supported by Law and Justice. At the beginning of 2012, SPZZ had only 20 MPs in the Sejm so it needed the support of other parliamentary factions ${ }^{25}$ because, according to Article 159 of the Polish Constitution, such a motion had to be submitted by at least $69 \mathrm{MPs}^{26}$.

On May 13, 2012, SPZZ, as a political party, proposed solutions of social character. During the press conference entitled "A strong family by the power of the state", politicians postulated the establishment of the institution of the Family Ombudsman. As fleshed out by SPZZ, this entity would have a legislative initiative and could have influence upon regulations concerning families. They advocated the introduction of the Polish Charter of Family Rights, based on the Charter of Family Rights, which the Holy See adopted in $1983^{27}$.

In September of the same year, MP Patryk Jaki presented a draft amendment to the Act on National and Ethnic Minorities. As reported by "Gazeta Wyborcza", "Solidary Poland's politicians now want to introduce a provision that if the results of the current census show that less than $20 \%$ of the representatives of minorities live in the municipality, the municipal authorities are to ask the Minister of Administration and Digitization to remove the municipality from the register. The boards would then be removed"28. Representatives of national minorities expressed their dissatisfaction with Ziobro. Indeed, Stefan Hładyk, the chairman of the Lemko Association, noted that the inhabitants of the Uście Gorlickie district had been trying for three years to place plaques with place names in Polish-Lemko language and thanks to public consultations their pos-

${ }^{25}$ [k.b.,w.w], Ziobryści razem z SLD i Palikotem ?, "Rzeczpospolita", 13.02.2012, no 36, p. A6.

${ }^{26}$ Art. 159 of the Constitution of the Republic of Poland of 2 April 1997, (Dz. U. 1997, No. 78 , item 483).

27 [w.w], Solidarna Polska skręca do centrum, "Rzeczpospolita", 11.05.2012, no 109, p. A8.

${ }^{28}$ B. Kuraś, Solidarna Polska nie lubi mniejszości, "Gazeta Wyborcza”, 10.09.2012, no 211, p. 6. 
tulate was fulfilled. Danuta Pietraszewska (PO), who in the 7th term of the Sejm served as a vice-chairwoman of the parliamentary committee of national and ethnic minorities, spoke out against the change of the law. In her opinion, the state should take care of every ethnic group ${ }^{29}$.

On September 15, 2012 the SPZZ Congress took place in Kutno. Here, the party got together to select its candidate for Prime Minister. Tadeusz Cymański, the party's European deputy, was elected. The president of the party Z. Ziobro said: "Poland needs a new hand, Poland needs a new Prime Minister" ${ }^{30}$. At a press conference, which took place on October 3, 2012, T. Cymański and Z. Ziobro presented a program for agreement on the appointment of a new government. It included demands for a benefit of up to 300 zlotys for families whose income would not exceed 1000 zlotys per person, creation of the Future Fund, extension of maternity leave, full access to crèches, abolition of immunities and return to the merger of the functions of Minister of Justice and Prosecutor General ${ }^{31}$. Zbigniew Ziobro's Solidary Poland, in presenting their candidate for the head of government, met with the Law and Justice party, which filed a constructive motion of censure for Donald Tusk's government and presented Professor Piotr Gliński's candidacy for technical prime minister.

In October, SPZZ deputies demanded that the anti-abortion law, in force since 1993, be tightened, although it was known in advance that their proposal had no greater chance of success. SPZZ postulated that the law should delete provisions that allowed for the removal of a pregnancy "if the pregnancy was caused by a prohibited act, if it poses a threat to a woman's life or health and if prenatal tests or other medical indications indicate a high probability of a severe and irreversible impairment of the fetus or an incurable disease that endangers its life" ${ }^{32}$. On Tuesday, October 23, 2012, a meeting of the Parliamentary Committee on Health and Social Policy was held, attended by about 60 MPs. After an hour of heated discussion, Dariusz Dziadzio from the Palikot Movement decided to end the committee's deliberations and put to a vote the only motion proffered - to close the list of Members asking to speak, which

\footnotetext{
${ }^{29}$ Ibidem.

${ }^{30}$ [b.a.], Ziobro: Cymański to nasz kandydat na premiera, wprost.pl, https://www.wprost. pl/kraj/347660/ziobro-cymanski-to-nasz-kandydat-na-premiera.html, on-line: 02.11.2015.

${ }^{31}$ Press Office of Solidary Poland, 10 programme proposals of Solidary Poland, salon24. pl, http://solidarna.salon24.pl/452352,10-postulatow-programowych-solidarnej-polsk, on-line: 13.12.2015.

${ }^{32}$ A. Kondzińska, PiS i Solidarna Polska: Wy chcecie zabijać dzieci, "Gazeta Wyborcza", 24.10.2012, no 249, p. 4
} 
was supported by 42 Members, while 22 were against ${ }^{33}$. After an unsuccessful attempt to change the anti-abortion law, SPZZ continued to fight for the votes of the right. Its deputies did not like the idea of the authorities of Częstochowa allowed in vitro procedures to be subsidized from local government money ${ }^{34}$. In November 2012, SPZZ deputy Beta Kempa asked the Sejm's committee for state control to support her motion to control NIK in Częstochowa. She argued her decision in the following way: "This is not a matter of a worldview dispute. I am part of the legislature and that is why I want to know on the basis of which law the municipality made the decision on in vitro funding. There is no law on in vitro in Poland, the bioethical law is not passed. In a moment it will turn out that others, on the same principle as Częstochowa, will subsidize euthanasia or flights to the moon". As B. Kempa emphasized, she did not want to threaten anyone with NIK, but only to get information whether the Częstochowa City Council could adopt such a resolution ${ }^{35}$.

In the same year, on December 8th, a congress of the party dedicated to the problems of the countryside was held. This was attended by a former PiS politician, and in 2012 a member of the party Poland Is Most Important (PJN) Wojciech Mojzesowicz. The party announced the submission of a bill to the Sejm, that would oblige the government to strive for subsidies for Polish farmers in the European Union, that are comparable to that of other farmers from the European Union. From 2013, the SPZZ planned to hold debates in each district under the slogan "Solidarna Wieś" (Solidary Village) and to create a "book of the deceived farmer", which would contain all the promises made to farmers by those in power. Jacek Bogucki and Jarosław Żaczek were to take care of agricultural matters in the party ${ }^{36}$.

On April 13, 2013 in Łódź, a nationwide convention was held. "Solidary Poland - the future for young people”, and was attended by B. Kempa, Jacek Kurski, Tadeusz Woźniak, Jan Ziobro and Z. Ziobro, who said: "We must make young people here, on the Vistula, not there, in Ireland, England or Austria, a place where could pursue their dreams, create a family, buy a house, a car and have a sense of security" ${ }^{37}$. The convention is entirely devoted to young people,

\section{Ibidem.}

34 The Częstochowa City Council has allocated PLN 110 thousand for 36 pairs to co-finance in vitro treatments in 2012. The subsidy for the procedure was up to 3 thousand PLN.

35 A. Kondzińska, D. Steinhagen, Ziobryści chca nastać NIK na Częstochowę za in vitro, “Gazeta wyborcza”, 07.11.2012, no 260, p. 4.

36 J. Kałucki, Solidarna Polska rusza na wieś, "Rzeczpospolita”, 05.12.2012, no 284, p. A8.

${ }^{37}$ Home page Zbigniew Ziobro's Solidary Poland, For the young, http://www.solidarna.org. pl/blogroll/dla-mlodych, on-line: 28.05.2015. 
their problems and prospects for the future. The attending politicians focused on the discussion on unemployment among young people, the lack of flats, and the extensive emigration of very often well-educated people. They announced free studies, regardless of the number of courses taken, as well as a reduction in social security contributions for an employer employing a young person. Moreover, 3\% of GDP was to be devoted to science, the construction of nurseries at universities and the introduction of an educational voucher ${ }^{38}$.

In mid-2013, the SPZZ proposed a draft for a New Constitution. MP P. Jaki, said: "The presidential elections are the most popular, which means that the social control of exercising power by the head of state is also the greatest. We call for the transfer of all power to the president while maintaining the controlling role of the Seym. The party voted in favor of the liquidation of the Senate, the National Broadcasting Council, a reduction in the number of deputies, single-member constituencies and the elimination of public funding for political parties ${ }^{39}$.

In August 2013, SPZZ submitted to the Sejm a bill on the reduction of pensions for former Security Service officers. This was prepared by MP P. Jaki. Politicians from Z. Ziobro's party did not hide their indignation that former security service officers received benefits in the amount of gross PLN 4,143. They thought it was way too much. Deputy P. Jaki's submission of the bill argued as follows: "These are definitely too high benefits - especially in that many opposition activists who were fired for their activities are now living in poverty, and the bastards who persecuted them live like donuts in butter" ${ }^{\prime 0}$. The bill of the SPZZ deputy provided for a reduction of pensions to PLN 1,490 gross. Politicians from other political options also spoke about the matter. Jarosław Zieliński, a PiS MP, said that SPZZ copied PiS ideas from a few years ago, which were not voted through in the Sejm. The PO deputy, Małgorzata Kidawa-Błońska said at that time: "We have already done it once and we cannot come back to it every two or three years, making further reductions, because it would not be fair, but revenge" ${ }^{\text {"11 }}$. In 2009, the Sejm adopted the security-service-prosecution act, which resulted in the granting of lower pensions to 41 thousand former functionaries of the PRL services and 9 persons sitting on the Military Council of National Salvation ${ }^{42}$.

\footnotetext{
${ }^{38}$ Home page Zbigniew Ziobro's Solidary Poland, For students, http://www.solidarna.org. pl/blogroll/dla-studentow, on-line: 28.05.2015.

${ }^{39}$ Home page Zbigniew Ziobro's Solidary Poland, New constitution, op. cit; W. Ferfecki, Konstytucja wedtug Ziobry i Palikota, "Rzeczpospolita", 2-3.05.2013, no 102, p. A6

${ }^{40}$ E. Olszyk, Partia Ziobry kontra emerytury przywódców PRL, “Rzeczpospolita”, 27.08.2013, no 199, p. A3.

${ }^{41}$ Ibidem.

${ }^{42}$ Ibidem.
} 


\section{Completion}

As indicated by the platform document and its political activity, Zbigniew Ziobro's Solidary Poland, as a conservative party, tried, among other things, to differentiate itself from the dominant party on the right side of the political scene, Law and Justice (PiS). The hypothesis put forward in the article, therefore, was verified positively because both parties fought for the same electorate, but both were distinguishable. SPZZ tried to convince right-wing voters to accept it and its program by means of program initiatives, yet it was not able to threaten the dominant position of the Law and Justice party on the right side of the political scene. This was confirmed by opinion polls, and according to a survey conducted by CBOS on 6-12 June 2013. According to this, only $2 \%$ of elligible voters wanted to vote for SPZZ. The same result was obtained by the party in a survey conducted by TNS Polska on 6-7 March 2014 $4^{43}$. The level of public support for SPZZ was verified by the elections to the European Parliament in $2014^{44}$ in which Z. Ziobro won only $3.98 \%$ of the vote, while PiS gained over $31 \%^{45}$. It seems, that SPZZ was close to suffering the political fate of the PJN party - a party that was formed after some politicians left PiS. PJN was a party that did not become an alternative for the voters, which was confirmed by the results of the elections to the Sejm in 2011, in which PiS received $29.89 \%$ of votes and PJN - only $2.19 \%{ }^{46}$.

In answering the first question, it should be noted that SPZZ did put forward new solutions: economic and social, as well as those devoted to the upholding of traditional values. This was confirmed in the ideological declaration and was an important element of the election program. SPZZ tried to present their program proposals by means of press conferences or by organizing congresses devoted to the problems of villages or young people. Therefore, these were the events by means of which SPZZ politicians were presented in the media - which was confirmed by the press articles used in the publication and in this way they

${ }^{43}$ [b.a.], Nowy sondaż poparcia partii politycznych, radiopik.pl, http://www.radiopik. pl/3,2745,nowy-sondaz-poparcia-partii-politycznych, on-line: 28.05.2015; [b.a.], Wzrosto poparcie dla PiS. Najnowszy sondaż wyborczy, wiadomosci.dziennik.pl, https://wiadomosci.dziennik.pl/polityka/artykuly/452887,pis-nadal-liderem-najnowszy-sondaz-wyborczy.html, on-line: 28.05.2015.

${ }^{44}$ More about the elections to the Sejm and Senate of the Republic of Poland in 2015, D. Wicherek, Udziat w wyborach Solidarnej Polski Zbigniewa Ziobro w latach 2014-2015, "Krakowskie Studia Małopolskie", Toruń 2017, no 22, pp. 45-49.

${ }^{45}$ Home page of the State Election Commission, Results of the European Parliament elections in 2014, https://pe2014.pkw.gov.pl/pl/, on-line: 03.12.2019.

${ }^{46}$ Home page of the State Election Commission, Sejm and Senate Election Results 2011, https://wybory2011.pkw.gov.pl/wsw/pl/000000.html, on-line: 03.12.2019. 
increased the party's recognition and could present their program proposals to the public.

In answering the second question, one can state that the party proposed initiatives in health care, workplaces, pensions, in dealing with the youth and young adults, but it also addressed issues related to the economy and public safety. Such efforts complemented the electoral program, and were an expression of political party activity in every area of life. After the mentioned elections to the European Parliament, which were a critical exam with regard to the importance of SPZZ on the political scene, cooperation of SPZZ with PiS began and the the United Right was formed - which has been in power in Poland since 2015.

\section{Bibliography}

- Constitution of the Republic of Poland of 2 April 1997, (Dz. U. 1997, No. 78, item 483).

- Chmaj M., Żmigrodzki M., Wprowadzenie do teorii polityki, Lublin 1996.

- Gulczyński M., Nauka o polityce, Warsaw 2007.

- Herbut R., Teoria i praktyka funkcjonowania partii politycznych, Wrocław 2002.

- Kowalczyk K., Rodzina partii politycznych w III RP, [in:] Partie i Systemy Partyjne w III RP, ed. K. Kowalczyk, Torun 2011.

- Sokół W., Partie polityczne i systemy partyjne w Polsce w latach 1991-2001, [in:] Wspótczesne partie i systemy partyjne. Zagadnienia teorii i praktyki politycznej, ed. W. Sokól, M. Żmigrodzki, Lublin 2003.

- Sokół W., Podziały wedtug kryterium ideologicznego i programowego. Rodziny ideologiczne partii politycznych, [in:] Wspótczesne partie i systemy partyjne, ed. W. Sokó1, M. Żmigrodzki, Lublin 2003.

- Wicherek D., Udziat w wyborach Solidarnej Polski Zbigniewa Ziobro w latach 20142015, “Krakowskie Studia Małopolskie”, Toruń 2017, no 22.

- [k.b.,w.w], Ziobryści razem z SLD i Palikotem ?, "Rzeczpospolita", 13.02.2012, no 36.

- [w.w], Solidarna Polska skręca do centrum, "Rzeczpospolita", 11.05.2012, no 109.

- B. Kuraś, Solidarna Polska nie lubi mniejszości, "Gazeta Wyborcza”, 10.09.2012, no 211.

- Ferfecki W., Konstytucja wedtug Ziobry i Palikota, "Rzeczpospolita", 2-3.05.2013, no 102.

- Kałucki J., Solidarna Polska rusza na wieś, "Rzeczpospolita”, 05.12.2012, no 284.

- Kondzińska A., PiS i Solidarna Polska: Wy chcecie zabijaćdzieci, "Gazeta Wyborcza”, 24.10.2012, no 249.

- Kondzińska A., Steinhagen D., Ziobryści chca nastać NIK na Częstochowę za in vitro, "Gazeta wyborcza", 07.11.2012, no 260.

- Majewski P., Ziobro: 700 zł na dziecko, "Rzeczpospolita", 16.12.2013, no 292.

- Olszyk E., Partia Ziobry kontra emerytury przywódców PRL, "Rzeczpospolita", 27.08.2013, no 199.

- [b.a.], Nowy sondaż poparcia partii politycznych, radiopik.pl, http://www.radiopik. pl/3,2745,nowy-sondaz-poparcia-partii-politycznych, on-line: 28.05.2015. 
- [b.a.], Solidarna Polska pokazała nowe logo i spot promujacy kongres założycielski, gazetaprawna.pl, on-line: 08.11.2015.

- [b.a.], Wzrosło poparcie dla PiS. Najnowszy sondaż wyborczy, wiadomosci.dziennik.pl, https://wiadomosci.dziennik.pl/polityka/artykuly/452887,pis-nadal-liderem-najnowszy-sondaz-wyborczy.html, on-line: 28.05.2015.

- [b.a.], Ziobro: Cymański to nasz kandydat na premiera, wprost.pl, https://www. wprost.pl/kraj/347660/ziobro-cymanski-to-nasz-kandydat-na-premiera.html, on -line: 02.11.2015.

- Home page of the State Election Commission, Results of the European Parliament elections in 2014, https://pe2014.pkw.gov.pl/pl/, on-line: 03.12.2019.

- Home page of the State Election Commission, Sejm and Senate Election Results 2011, https://wybory2011.pkw.gov.pl/wsw/pl/000000.html, on-line: 03.12.2019.

- Home page Zbigniew Ziobro's Solidary Poland, Health, http://www.solidarna.org. pl/blogroll/ochrona-zdrowia, on-line: 28.05.2015.

- Home page Zbigniew Ziobro's Solidary Poland, About work, http://www.solidarna. org.pl/blogroll/miejsca-pracy, on-line: 28.05.2015.

- Home page Zbigniew Ziobro's Solidary Poland, Declaration of ideas, http://www. solidarna.org.pl/deklaracjaideowa, on-line: 28.05.2015.

- Home page Zbigniew Ziobro's Solidary Poland, District Women's Fora, http://www. solidarna.org.pl/blogroll/dla-kobiet, on-line: 28.05.2015.

- Home page Zbigniew Ziobro's Solidary Poland, Economy and entrepreneurship, http:// www.solidarna.org.pl/blogroll/gospodarka, on-line: 28.05.2015.

- Home page Zbigniew Ziobro's Solidary Poland, Family, http://www.solidarna.org.pl/ blogroll/rodzina,on-line: 28.05.2015.

- Home page Zbigniew Ziobro's Solidary Poland, For students, http://www.solidarna. org.pl/blogroll/dla-studentow, on-line: 28.05.2015.

- Home page Zbigniew Ziobro's Solidary Poland, For the young, http://www.solidarna. org.pl/blogroll/dla-mlodych, on-line: 28.05.2015.

- Home page Zbigniew Ziobro's Solidary Poland, http://www.solidarna.org.pl, on-line: 28. 05. 2015.

- Home page Zbigniew Ziobro's Solidary Poland, New Constitution, http://www.solidarna.org.pl/blogroll/nowa-konstytucja, on-line: 28.05.2015.

- Home page Zbigniew Ziobro's Solidary Poland, Not for stealing, http://www.solidarna. org.pl/blogroll/nie-dla-kradziezy, on-line: 28.05.2015.

- Home page Zbigniew Ziobro's Solidary Poland, Pedophile register, http://www.solidarna.org.pl/blogroll/rejestr-pedofilow, on-line: 28.05.2015.

- Home page Zbigniew Ziobro's Solidary Poland, Pensioners, http://www.solidarna. org.pl/blogroll/emeryci-i-rencisci, on-line: 28.05.2015.

- Home page Zbigniew Ziobro's Solidary Poland, Programme Declaration New Hope, http://solidarnapolska.pl/program, on-line: 08.11.2015.

- Home page Zbigniew Ziobro's Solidary Poland, Security, http://www.solidarna.org. pl/blogroll/bezpieczenstwo, on-line: 28.05.2015.

- Home page Zbigniew Ziobro's Solidary Poland, Stop expensive energy, http://www. solidarna.org.pl/blogroll/pakiet-klimatyczny, on-line: 28.05.2015. 
- Press Office of Solidary Poland, 10 programme proposals of Solidary Poland, salon24.pl, http://solidarna.salon24.pl/452352,10-postulatow-programowych-solidarnej-polsk, on-line: 13.12.2015.

- Twitter, Jacek Kurski's profile, information from 17.10.2015 “Tomorrow SPZZ will submit to the Sejm a bill on the national register of paedophiles, all paedophiles, whoever they are. This is a real fight against the problem", twitter.com, https://twitter. com/kurskipl/status/390915444426964993, on-line: 28.05.2015.

Summary: The aim of the article was to analyze the program initiatives of Zbigniew Ziobro's Solidary Poland in the years 2012-2014 - a time before the political party became a part of the United Right, a Frankenstein's monster cobbled together as a result of the agreement between Law and Justice and Poland Together Jarosław Gowin (Agnreement). In the first part of the article, the author presents the program proposals of the political party, while in the second part, he discusses the activities of its members by presenting the initiatives taken in relation to the election program. At the end of the article the author summarizes the activity of the political party.

Keywords: political party, Solidary Poland, election program, right

\section{Założenia programowe Solidarnej Polski Zbigniewa Ziobro w latach 2012-2014}

Streszczenie: Celem artykułu była analiza inicjatyw programowych Solidarnej Polski Zbigniewa Ziobro w latach 2012 - 2014 zanim partia polityczna weszła w skład Zjednoczonej Prawicy, powstałej w wyniku porozumienia pomiędzy Prawem i Sprawiedliwością oraz Polską Razem Jarosława Gowina (Porozumienie). W pierwszej części artykułu, autor przedstawia propozycje programowe partii politycznej, natomiast w drugiej omawia działalność jej członków poprzez zaprezentowanie podejmowanych inicjatyw w odniesieniu do programu wyborczego. W zakończeniu artykułu autor podsumowuje działalność partii politycznej.

Słowa kluczowe: partia polityczna, Solidarna Polska, program wyborczy, prawica 